\title{
'We Are Strangers Before You and Sojourners, As All Our Fathers Were' (1 Chr 29:15). The Old Testament's Contribution to the Ethical Issue of Migration'
}

\section{Adam Mackerle}

For Christians the Old Testament is the 'Word of God', 'profitable for teaching, for reproof, for correction, and for training in righteousness, that the man of God may be complete, equipped for every good work' (2 Tim 3:16-17). By right, Christians turn to it when they search for 'what is good in the Lord's eyes' and what is evil, viz. with questions of moral or ethical character. One of the questions that 'belongs among the most pressing issues of the contemporary globalised world'2 and which has especially recently become a very acute social, political, economic and security topic, is the problem of migration. But in the first place it is an ethical topic, insofar as the one we are facing is not the political citizen of another country, an item of the labour force, someone requesting access to our resources, or a potential enemy, but first of all a human being. ${ }^{3}$

Using the Bible in ethical discourse is the subject of a live discussion. If on the one hand we expect God's Word to be 'a lamp to my feet' and 'a light to my path' (Ps 119:105), on the other hand, Biblical texts originated in times that were alive with other issues and problems, and many of the problems of the contemporary world was non-existent; many of those they knew and solved were different in character, in their causes and form; ${ }^{4}$ and finally it happens that although a contemporary problem is solved in the Bible and is sufficiently clear and applicable, we find it morally difficult to accept that solution, because it goes against our conscience. ${ }^{5}$ So methodology in Bibli-

1 This study is a result of scholarly research within project GA15-15894S of the Czech Science Foundation 'Ethical Aspects of Pre-Exile Minor Prophets'.

2 Petr ŠTICA, Cizinec v tvých branách: biblické podněty pro etickou reflexi migrace, Praha: Karolinum, 2010, p. 105.

3 For this reason and rightly so Carroll, Štica, as well as Damohorská and others begin the discussion of foreigners in the Old Testament by reference to the creation of the human being in God's image (Gen 1:27). Cf. M. Daniel CARROLL R., How to Shape Christian Perspectives on Immigration? Strategies for Communicating Biblical Teaching, in: Religion and Politics in America's Borderlands, ed. Sarah AZARANSKY, Lexington Books, 2013, p. 68; Petr ŠTICA, Cizinec v tvých branách, pp. 84-89; Pavla DAMOHORSKÁ, Postavení cizinců v Pentateuchu ve vztahu k etice, in: Bible a etika v kontextu doby a myšlení, Kamila VEVERKOVÁ et al., Chomutov: L. Marek, 2014, p. 84.

4 The problems of applying Biblical texts to modern ethical issues are enumerated and explained in many books and studies. Here I will only mention the extreme position of Rodd, according to whom the differences between the Biblical text and its world on the one hand and our world on the other are such that applying Biblical texts to our time is de facto impossible. Although his conclusions are difficult to accept, his analysis of the individual problems is developed in detail and the arguments he raises must be taken into account. Cf. Cyril S. RODD, Glimpses of a Strange Land. Studies in Old Testament Ethics, Edinburgh: T \& T Clark, 2001.

5 An example may be the very existence of slave law contained not only in all the three great legal codes of the Pentateuch, but appearing for example also in the New Testament letter to Philemon. Many readers have no problem appealing to the Old Testament when rejecting homosexuality, but they would regard applying the Old Testament sanctions associated with it as unethical and monstrous. This shows that in practice our moral judgment has priority over the immediate meaning of God's Word. 
cal ethics is an uneasy topic and it is beyond the scope of this study to deal with it. Although the Bible is not the only instance to which our ethics appeals and from which it draws, ${ }^{6}$ it is nonetheless a necessary reference text, to which ethics must turn when searching for attitudes and solutions. In this work we start from the study by Birch and Rasmussen, according to whom it is essential to take into account all texts that have something to say on the issue at hand, regardless of their possible controversial character or mutual contradiction. ${ }^{7}$ This study will therefore aim to map what and how the Old Testament says on the issue of migration and sketch out preliminary conclusions that could contribute to the formation of a Christian's attitude towards the arriving refugees. The conclusions will not be exhaustive, since with respect to the issue breadth it is not possible to go through all of the relevant texts; ${ }^{8}$ also, other texts can have a bearing on the issue, even if they have nothing to do with migration at first sight. ${ }^{9}$ Neither will the conclusions issue in normative statements, but 'merely' mediate the perspective (or perspectives) that Old Testament texts take on the issue. The intention is to take a look at what is happening ${ }^{10}$ from a new perspective contained in the Word of God.

In the course of the history narrated by the Old Testament, Israel encountered the migration of individuals and nations; this was in the role of the host, as a migrant searching for new refuge, and as an impartial observer. In that, it theologically reflected on all of these situations in some way or another. Therefore this study has two main parts. The first one deals with texts describing the migrant experience of Israel, and the second focuses on its role as the host. This will make it possible to view the same problem from both aspects; without such a comparison, no discussion of the topic in the Old Testament would be complete.

6 Cf. the classical study James M. GUSTAFSON, The Place of Scripture in Christian Ethics, in: Theology and Christian Ethics, James M. GUSTAFSON, Philadelphia: Pilgrim Press, 1974, especially pp. 144-145; further Bruce C. BIRCH and Larry L. RASMUSSEN, Bible \& Ethics in the Christian Life, Minneapolis: Augsburg, 1989, especially pp. 11-16. Tom DEIDUN, The Bible and Christian Ethics, in: Christian Ethics. An Introduction, ed. Bernard HOOSE, London: Cassell, 1998, p. 27-28 summarises it under concepts common in the Catholic milieu: correct reason, Scripture, tradition and Magisterium.

7 Cf. Bruce C. BIRCH and Larry L. RASMUSSEN, Bible \& Ethics in the Christian Life, especially pp. 186-188. But for the authors it is just one of the possible uses of the Bible in ethics.

8 In this paper I intentionally do not deal with some texts that may appear important, because they clarify aspects of perceiving the issue of the foreigner and the migrant in the Old Testament that are not accounted for in this study. It is first of all the issue of perceiving the 'foreign' (see especially the overview study Maria HÄUSL, Zugänge zum Fremden: Einblicke in die alttestamentliche Forschung, in: Zugänge zum Fremden. Methodisch-hermeneutische Perspektiven zu einem biblischen Thema, ed. Gerlinde BAUMANN et al., Peter Lang, 2012, p. 7-29), i.e., among others, prophetic pronouncements against the nations, as well as eschatological visions speaking of the unification of nations in the single true cult of the Lord and establishment of universal peace. In discussing the experience of Israel as a migrant I leave out the experience of the violent migrant, i.e., texts describing the violent seizure of land and eradication of original inhabitants. I do not mention the books of the Maccabees, the problem of the influence of strange cultures and the fight against excessive assimilation on the part of the Jews, etc. A separate chapter is constituted by the pronouncements against Edom, since they probably derive from the historical situation of the semi-peaceful seizure of the south of Judea by the Edomites, and are therefore marked by a bitterness on the part of the Jews issuing out of this experience. All that should find a place in this study, which is lacking. That is why I sketch out merely what I regard as the main lines of Old Testament ethical deliberation on the problem of migration and leave the others to the reader's further study.

9 I am alluding to the great problem of a straightforward application of those Biblical texts that directly concern the topic based on keywords, etc. For there may often be more important texts that at first glance have nothing to do with the given ethical problem. An example may be using Luke's parable of the Good Samaritan and others, surprising texts in this context, on the issue of abortions; cf. Frederick Christian BAUERSCHMIDT, Being Baptized. Bodies and Abortion, in: The Blackwell Companion to Christian Ethics, ed. Stanley HAUERWAS and Samuel WELLS, Blackwell, 2004, pp. 259-262; Richard HAYS, The Moral Vision of the New Testament. Community, Cross, New Creation, San Francisco: HarperSanFrancisco, 1996, pp. 444-461; and others.

10 Cf. a very interesting study on the formation of a Christian by Biblical (and other) texts William SCHWEIKER, Images of Scripture and Contemporary Theological Ethics, in: Character and Scripture. Moral Formation, Community, and Biblical Interpretation, William P. BROWN et al., Grand Rapids: Wm. B. Eerdmans, 2002, pp. 34-52. 


\section{Texts from the migrant's point of view}

\subsection{The forefathers and the sojourn in Egypt}

The history of Israel is from its very beginning the history of migrants. From his native land, Abram with his father Terah and nephew Lot and the families set out for Canaan (Gen 11:31). In the Chaldean Ur the Lord addresses Abram and challenges him to set out for Canaan, 'from your country and your kindred and your father's house' (Gen 12:1), when he was already seventy-five, i.e., quite old. It may be said that he lives the life of a nomad, i.e., a migrant 'by vocation'; but Abram leaves his security in Mesopotamia for the promise that he will receive another land in Canaan. He leaves one security to gain another. Here, as well as in other Old Testament places, the situation of a migrant is perceived as transitory, aiming towards an ideal, which is the constant and permanent ownership of land. ${ }^{11}$ All journeying in the Pentateuch is always aimed towards the hope of a land that God has promised to give. But in Abra(ha)m's life, moments come when migration is outright involuntary. Because of famine Abram leaves for Egypt (Gen 12:10-20). It is interesting to observe the anxiety of the 'refugee' Abram concerning his own and his wife's safety in a foreign land. He is similarly anxious in Gerar (Gen 20:1-18) and an analogical story is associated with Isaac (Gen 26:1-14). Both were obliged to engage in disputes over wells with the local inhabitants (Gen 21:22-34; 26:15-35). Isaac's son Jacob leaves his family for fear of his brother (and at the same time with the intention of finding a bride) and flees for Mesopotamia to join his mother's family. But his uncle Laban treats him like a poor relative, who must work hard to gain a position. It is always the migration of individuals, or families and small, family kinship-based social groups.

Besides the fact that the lives of the fathers of the Israeli nation are a story of migrants without a home in a foreign land, this unfavourable life situation is emphasised in the ritual formula recited on the occasion of the yearly offering of the first fruits of the harvest in the Temple (Deut 26:5): 'A wandering Aramean was my father. ${ }^{\text {'2 }}$ So it is not merely a secondary, contingent aspect of their life, but something typical for them, which is at the root of the Old Testament Israeli consciousness: we are the descendants of migrants who had no permanent land and were foreigners in every country.

With the Joseph narrative the epopee of leaving for Egypt begins (Gen 37:39 - Ex 15), which is a typical migration crisis at a national level. It all begins with the story of a young man who was sold by his own family to a foreign land. There, due to a dynamic career growth, he began as a prisoner and ended as a government minister. He must have had a good command of the Egyptian language, assumed an Egyptian name (Zaphenath Paneah, Gen 41:45), married an Egyptian and had children by her. He most probably also began to dress in the Egyptian fashion, shave his head and paint his face, which explains why his brothers had no idea who they were talking to. He later had the body of his father Jacob embalmed; similarly, his own body was embalmed after his

11 Cf. Josef Bohumil SOUČEK, Příchozí a poutníci. Biblicko-theologická studie, in: Teologické a exegetické studie, Josef Bohumil SOUČEK, Praha: Centrum biblických studií AV ČR a UK, 2002, pp. 109-127. Cf. the pragmatic evaluation of the life situation of a stranger in Sir 29:23-28.

12 Some translations do not regard 'my father wandering Aramean' as a separate sentence, but as the subject of the following sentence, which weakens the statement's significance (for example B21 or the Bible of Kralice). In the Hebrew text it is a separate nominal sen-

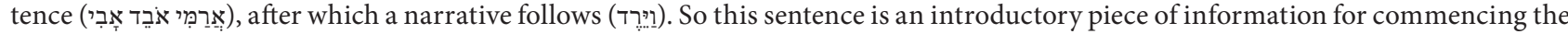
narrative of going down to Egypt, yet nonetheless remains a separate complete statement. 
death. ${ }^{13}$ For his merits the host community let him stay with them and even allowed his family to move in, granting them their own territory within Egypt. But as time passed (according to Ex 12:4 Israel's sojourn in Egypt ${ }^{14}$ lasted 430 years) this foreign family grew to unexpected dimensions; it continued to live in its territory, which had become a ghetto of a kind; the Egyptians (the host community) no longer thought of how the ancient ancestor of these foreigners living in the heart of their land had saved their ancestors, but were concerned about the excessive number of these foreigners, which could pose a threat by allying with Egypt's enemies and turning against their hosts (Ex 1:9-10). Following our media of recent times makes such an anxiousness for one's own safety obviously understandable and natural. So the decision of the home population is clear: They must be rid of the foreigners and the best way to achieve that is genocide (murdering newborn boys) together with forced labour (building cities). ${ }^{15}$ This provokes the immigrants (who have been living in the country for several generations) to an uprising, escalating in violence and murder. This uprising is headed by a descendant of the foreigners (an Israelite) who was brought up in the best home (Egyptian) tradition including the assuming of an Egyptian name and with foreign experience (he is even married to a Midianite). ${ }^{16}$ Although the Old Testament clearly shows on which side the author's sympathies are, contemporary European states find themselves in the role of Egypt and face very similar problems that have arisen in a similar way.

That most well-known Old Testament story is ultimately nothing else than a great migration crisis issuing in a clash between the host community and the immigrant community. ${ }^{17}$ Right at the very beginning of Israel's history there is their national, i.e., no more merely family experience of unwanted immigrants, who have suddenly become unwanted in a country where they had been living for several generations. As in the case of the 'wandering Aramean' this experience would also have far-reaching consequences for Israel's self-perception and theological reflection.

\subsection{The experience of the Babylonian captivity and diaspora}

The migration of individuals and smaller groups is sometimes mentioned even after Israel had settled in Canaan (Elimelech and his family leave for Moab because of a famine [Ruth 1:1-3], Jeroboam seeks political asylum in Egypt [1 Kings 12:40], etc.), but Israel as a nation has its own land. But the issue of migration and the problem of cohabitation with the majority host society appear again in full strength at the moment of the Babylonian captivity and when the Jewish diaspora is formed and develops. Tobit and his family are displaced in a foreign land, as is the family of Sarah, Daniel and his friends, the Jews in the Book of Esther, etc. The books that have risen out of this experience reflect the heated question of the mutual cohabitation of the populations and its rules.

13 Cf. M. Daniel CARroll R., Biblical Perspectives on Migration and Mission: Contributions from the Old Testament, Mission Studies $1 / 2013$, p. 14.

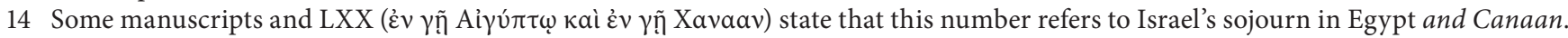
Even if this possibility was taken into account, it would still be a very long stay.

15 M. Daniel CARROLL R., How to Shape, p. 70 points out the mutual contradiction between the two regulations, i.e., the concurrent use of forced labour and genocide. Thereby he uncovers an obvious clash of two opposing interests of the host society - making use of the labour force and the concurrent limitation of the number of immigrants, a phenomenon not absent from contemporary national immigration policies.

16 Moses himself lived the greater part of his life as a refugee running away from his punishment for killing the Egyptian. His awareness

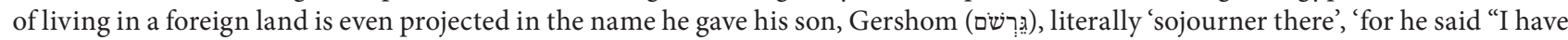
been a sojourner in a foreign land."' (Ex 2:22).

17 That is how the 'Egyptian crisis' is interpreted for example by Wis 19:13-16. 
The issue of assimilation is treated most markedly, albeit implicitly, by the first half of the Book of Daniel, especially in chapters $1-3$ and $6 .{ }^{18}$ The stories are situated in the Babylonian diaspora and the main heroes are the Jewish 'young men' who are to be re-educated at the Babylonian royal court. The first chapter concentrates on enumerating all that they accept from their involuntarily chosen host: new names, food, and education. If names signify identity and food the physical possibility of surviving, then education concerns not only the ability to write, but the knowledge of the entire Babylonian literary (and thereby religious) culture. The Jewish heroes create their own diet, most probably as a means of symbolically keeping their own, distinct identity. The following chapters also indicate a great, in fact almost absolute level of assimilation. The young men are regarded as part of the Babylonian wise men, so that they are to be slaughtered with them (Dan 2:13); but Daniel intervenes, fulfils the king's wish, and so saves not only himself and his Jewish colleagues, but all the other wise men as well. Chapters 3 and 6 especially underline the loyalty of Daniel and his three colleagues, being such a loyalty that even Daniel's opponents are obliged to acknowledge that they 'shall not find any ground for complaint against this Daniel unless we find it in connection with the law of his God' because 'he was faithful' (Dan 6:4.5). Daniel is accused by his Babylonian colleagues precisely because of his faithfulness and loyalty to the king and out of jealousy; the case of the three Jewish young men in Dan 3 is similar in many respects.

Nonetheless, where the faith and religious practice of the Jewish heroes is attacked, situations of crisis arise in which loyalty is pushed to its limit. In Dan 3 the king's command is in direct contradiction with the First Commandment. In Dan 6 it is the same commandment, but here the king's command (without the king's full knowledge) is formulated so as to be in direct contradiction with Daniel's religious practice. In both cases these are the only, yet unambiguous, limits of assimilation.

The narratives of the Book of Esther (the Persian period) and the Book of Tobit (the Assyrian captivity) are set in a similar milieu of the life of the Jews within a majority heathen society, albeit coherent reflection of the mutual relationship is rather different and less extensive. All three books (Daniel, Esther and Tobit) grapple with the possibility of there being persecution of the Jews for their 'distinctiveness', which is perceived primarily as a religious distinctiveness. In the Book of Esther, Haman's accusation sounds very xenophobic ('There is a certain people scattered abroad and dispersed among the peoples in all the provinces of your kingdom. Their laws are different from those of every other people, and they do not keep the king's laws...' (Esth 3:8)) and it is apparently intentionally exaggerated - they are the words of someone who is looking for the slightest pretence for destroying the nation - but in fact it is a personal feud (Esth 3:1-4). On the other hand, the book emphasises Mordecai's loyalty to the king (Esth 2:21-23).

Tobit served the Assyrian king Shalmaneser and was a purchaser for him in Media (Tob 1:13-14). Similarly his nephew Ahiqar 'had been chief cupbearer, keeper of the signet ring, treasury accountant, and credit accountant' (Tob 1:22). Tobit's fate depends to a great extent on his faithfulness to the law of God. He himself underlines that even after the deportation he still observes the dietary laws (Tob 1:11) and performs deeds of mercy, in particular feeding the hungry and burying the dead (Tob 1:17-18). These activities constitute a breach of the law of the 'host' country, but also a fulfilment of God's commandments. In all other ways Tobit and the other Israelites are

18 The following view of assimilation and its limits in Dan 1-6 is discussed in more detail in Adam MACKERLE, Danielovy dvorské př́iběhy jako vzor chování Žida uprostřed pohanské společnosti (Dan 1-6), Studia Theologica 1/2007, pp. 42-55. 
apparently fully integrated into the life of Assyrian society, although Tobit also voices an appeal for endogamous marriage (Tob 4:12-13). ${ }^{19}$

\subsection{The life experience of an individual: 'I am a stranger and an exile'}

In this context, two Old Testament texts are worth mentioning (Ps 39:13 and 1 Chr 29:15). They

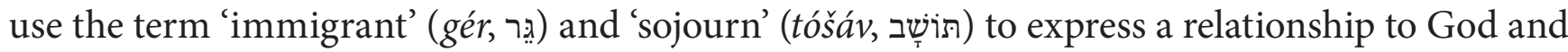
perceiving oneself and the finitude of one's own life on Earth. The extensive practical experience of the immigrant gives rise to an image expressing the essence of human existence as such. The psalmist says that 'I am a sojourner with you, a guest, like all my fathers'. With these words he expresses the same as in the rest of his prayer, namely that human existence is brief and the human being himself a mere 'breath' (הֶֶֶ). The Chronicler places almost the same words in David's mouth: 'For we are strangers before you and sojourners, as all our fathers were. Our days on the earth are like a shadow, and there is no abiding'. With these words David expresses the nothingness of the human being before God, while praying over the gifts presented for the construction of the temple. The wording of Ps 119:19.54 is similar. These texts emphasise the transient, vulnerable character of the existence of every individual in earthly life. Together with that, other aspects of this state/attitude come to the fore, namely mercy and dependence. By comparison with the fathers, who were also immigrants, this term newly defines the Israelites not territorially, but religiously: not by relationship to land, but by relationship to God. ${ }^{20}$ So the concept of 'sojourner' gradually changes into a theological concept, which will come into full use in the New Testament.

The Old Testament simile of the human life as the life of a sojourner is taken up and recalled in Heb 11:13, when the author summarises the attitude of the Old Testament forefathers: 'having

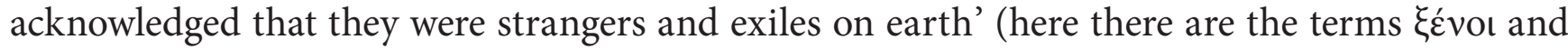
$\pi \alpha \rho \varepsilon \pi i \delta \eta \mu \mathrm{o})$. Peter in 1 Pet 2:11 urges the beloved ones to perceive themselves as sojourners and exiles and to behave accordingly. ${ }^{21}$ Although Peter's text is probably the best well-known text employing the foreigner motive, this simile had occurred already in the Old Testament and, when face to face with real migrants, it should remind Bible readers that their lives are essentially the same. On the other hand, a settled and peaceful life is unusual and 'non-standard', as it can induce the impression of security, self-sufficiency and safety.

\section{Texts from the host's point of view}

\subsection{Legal regulations}

In discussing the Old Testament in relationship to migration, the first - and sometimes even the only or the main ${ }^{22}$ - to be mentioned are the legal texts regulating the stay of foreigners in Isra-

19 At least according to some manuscripts; in the Sinai Codex the passage 4:7-19 is missing.

20 Cf. José E. Ramírez KIDD, Alterity and Identity in Israel. The ר in the Old Testament, Berlin - New York: Walter de Gruyter, 1999, pp. 104-107. Of course this nuance in meaning throws new light on the conception of 'sojourner' in the law codes of the Pentateuch (ibid).

21 For more see Dominik OPATRNÝ, Křestané jako cizinci podle Prvního listu Petrova, Studia theologica 4/2007, pp. 24-40.

22 Cf. two short studies focusing on comparing the Old Testament law concerning immigrants and the contemporary law in Canada and Australia, which are limited to this legal context, and therefore to these Old Testament legal texts. These are Mark GLANVILLE, Ancient Laws and New Canadian Refugee Legislation: Evaluating Bill C-31 in Light of the Book of Deuteronomy, Refuge 1/2013, pp. 115-119; Zalman KASTEL, Love the Stranger. Looking to the Torah for Guidance on Immigration Policy, Tikkun Magazine 3/2013, 
el's territory. The key term for immigrants in the legal texts is the word $\operatorname{ger}(\urcorner),{ }^{23}$ in two major meanings.

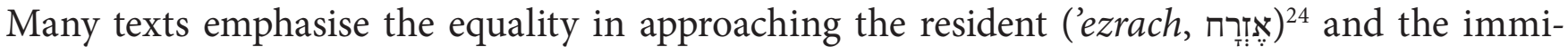
grant (gér, ר̊). They are prevalent in the Holiness Code (Lev 17-25), ${ }^{25}$ and similar statements are also found in the Decalogue when discussing the day of rest (Ex 20:10; Deut 5:14; similarly in Ex 23:12), in the Deuteronomic Code (Deut 24:14), and elsewhere. ${ }^{26}$ But other verses explicitly emphasise the principal legal equality when they state that 'there shall be one statute for you and for the stranger who sojourns with you... You and the sojourner shall be alike before the Lord. One rule and one law shall be for you and for the stranger who sojourns with you' (Num 15:15-16), or elsewhere, that 'You shall have the same rule for the sojourner and for the native' (Lev 24:22). ${ }^{27}$ Other individual laws apply and emphasise this equality in different spheres of life: in performing justice (Deut 1:16), in dealing with the poor (Deut 24:14), and in the right to rest on festive days (Ex 20:10; 23:12; Deut 5:14). The same rules and duties hold for all. The regulations concerning incest and sexual relationships in Lev 18 apply to all (see Lev 18:26), as do the regulations concerning Passover in Ex 12 or in Num 9:10-14, both with the concluding generalising statement that 'There shall be one law for the native and for the stranger who sojourns among you.' (Ex 12:49; see Num 9:14) The fast on the Day of Atonement also applies to all (Lev 16:29), as do the laws regarding blood consumption (Lev 17:8-15), the consequences of offerings to Molech (Lev 20:2), the regulations on offerings and some sacrifices (Lev 22:18; Num 15:14) or on blasphemy (Lev 24:16), and the regulations on cities of refuge (Num 35:15), etc. Even the appeal for the regular public reading of the law on the Feast of Tabernacles every seventh year holds for both residents and immigrants 'that they may hear and learn to fear the Lord your God, and be careful to do all the words of this law' (Deut 31:12). The emphasis is placed on the same rules in the cultic and religious sphere, but the recurrent generalising statements about the same law for immigrants and residents and the different spheres of life show a basic application of the general principle of 'one law for all'. This 'one law' does not distinguish between the immigrant and the resident and pervades all spheres of human life..$^{28}$

pp. 51-53. On the one hand it is understandable, because the legal texts of two cultures are being compared and neither author claims that he is attempting a complete elaboration of the topic, on the other hand the claim seems to suggest itself that Old Testament legal texts are sufficient for understanding the whole issue. Neither of the two studies pays attention to whether when the Old Testament speaks of immigrants it really means the same as the modern law of Canada or Australia and to what extent other circumstances are similar or different.

The emphasis on legal texts is also evident in studies available in the Czech language, for example Petr ŠTICA, Cizinec v tvých branách; or Pavla DAMOHORSKÁ, Postavení cizinců v Pentateuchu ve vztahu k etice; similarly in the Czech translation Enzo BIANCHI, Při jetí cizince, Praha: Pastorační středisko při Arcibiskupství pražském, 1998.

23 The Old Testament also knows the term נָכְִרי a negative term signifying rather 'a group of foreigners maintaining bonds with their original home' (Pavla DAMOHORSKÁ, Postavení cizinců v Pentateuchu ve vztahu k etice, p. 86). It signifies something 'foreign', 'heterogeneous', that does not fit and does not conform. The meaning of the term זָ is similar. Cf. also Petr ŠTICA, Cizinec v tvých branách, pp. 28-32.

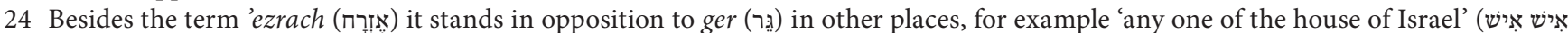

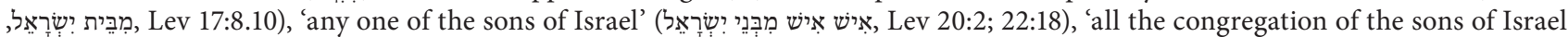

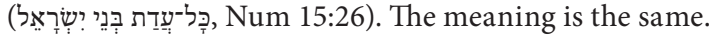

25 See Lev $17: 8,10,12,13,15 ; 18: 26 ; 19: 3.34 ; 20: 2 ; 22: 18 ; 24: 16,22$.

26 I.e., besides the main law codes and the Decalogue. It is, for example, the text concerning the celebration of Passover (Ex 12:19,48,49), Lev 16:29; Num 9:14; 15:14,15,16,17,26,29,30; 19:10; 35:15; Deut 1:16; 29:10; 31:12.

27 Cf. also Ex 12:49; Lev 24:22; Num 15:15-16,29-30; Deut 1:16.

28 Deut 14:21 distinguishes between immigrants and residents when it forbids residents to consume carrion, but immigrants can eat it and it can be sold to a foreigner (נָכְְרי). On the other hand, Lev 17:15 evaluates the situation when someone eats carrion (or something that has been torn by a beast) the same for an immigrant and a resident, so it seems that for the Leviticus the distinction between an immigrant and a resident does not hold even in this case. Also, the distinction between to give (to an immigrant, the verb נכתן) and to sell (to a foreigner, the verb מכר) is not insignificant. Other cases are buying a slave in Lev 25:44-55, where this distinction is justified by the redemption from Egypt, or celebrating Passover in Deut 16:1-8, where immigrants are not mentioned. 
Another context in which legal texts operate with the term for immigrants is 'awarding benefits'. Especially Deuteronomy operates with a group of disadvantaged and vulnerable persons, in which it normally includes widows, orphans and immigrants. ${ }^{29}$ All three groups are characterised by not being able to rely on a broader family structure, which would secure a means of livelihood and protection for them. That is why they must be protected (Deut 24:17), even on the penalty of being cursed (Deut 27:19); that is why they (and with them the Levites) are allocated tithes every third year (Deut 14:29; 26:12-13), with them the Israelite is to rejoice on the Feast of Weeks and Feast of Tabernacles (Deut 16:9-17) or when offering the first fruits of the harvest and is to share with them the good things God has granted to him (Deut 26:11); the gleanings of the harvest in the field, orchard or vineyard are also designated for the immigrants, orphans and widows (Deut 24:19-21).

Especially in this second case a key motivation is emphasised, which best corresponds to the immigrants (rather than widows and orphans), namely the reminder of the Egyptian slavery: 'for you were sojourners in the land of Egypt.' (Ex 22:21) ${ }^{30}$ Precisely this significant link between their own experience of immigrants and their current role of hosts is to function as a stimulus to grateful and similar openness. Deut 10:18-19 says that '[the Lord] executes justice for the fatherless and the widow, and loves the sojourner, giving him food and clothing. Love the sojourner, therefore, for you were sojourners in the land of Egypt.' It is as if the author wanted to say that God had taken Israel under his protection at the time of its greatest distress precisely because of his love for widows, orphans and immigrants, and that he now expects Israel to behave towards these categories of persons in the same way. ${ }^{31}$ Being an immigrant is not dishonest or a reason for discrimination. If the Old Testament lists immigrants next to widows and orphans, it sees them as persons disadvantaged by their life circumstances, in need of help and protection, who will find it difficult to obtain land, which in the Old Testament is subject to hereditary rights and ancestral claims. ${ }^{32}$ Quite on the contrary, the Israelites are expected to behave towards them as to their own kin, and they are even commanded to love them (Lev 19:33-34). The Lev 25:35 text reverses the simile and urges the reader to behave towards his impoverished brother as to an immigrant, i.e., welcomingly and well. The reference to the Egyptian experience is primary here and gives meaning to all of these regulations. To treat immigrants badly means to deny the essence of the history of salvation, the meaning of God's liberation of Israel from Egypt. The extreme formulation in Lev 25:23 does not speak of the Egyptian experience as a matter of the past, but relates it to the present. Before God the Israelites are still 'merely' immigrants, they are strangers in the (Lord's) land, in which they are tenants and which they must not sell permanently: 'The land is mine, for you are strangers and sojourners with me.' Here the awareness of one's own uneasy situation is applied to the way land is to be sold, but this statement also has consequences for the relationship to strangers, as it reminds one of the vulnerable state of the human being who owes his safety and

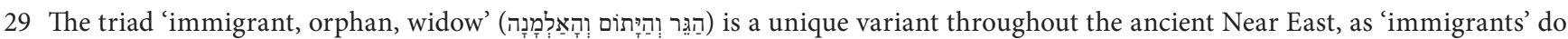
not appear in these contexts and formulations in any extra-Israelite texts. Within the Old Testament it is a typically and exclusively Deuteronomist formulation, although in the context of widows and orphans, immigrants also appear in Ex 22:20-21, and more loosely next to 'the poor' (עִָָ in Lev 19:10 and 23:22. Cf. José E. Ramírez KIDD, Alterity and Identity in Israel, pp. 35-42.

30 For other occurrences see Ex 23:9; Lev 19:34; 23:22; Dt 16:11; 24:17,19; 26:11.

31 In this sense the two formulations - i.e., the reference to the historical experience in Egypt and to God's love for the foreigner - are mutually interconnected and need not be perceived as two separate justifications, as M. Daniel CARROLL R. repeatedly states. Cf. for example How to Shape, p. 73; he speaks of a third motivation, which is God's blessing, in the paper Welcoming the Stranger. Toward a Theology of Immigration in Deuteronomy, in: Four Our Good Always. Studies on the Message and Influence of Deuteronomy in Honor of Daniel I. Block, ed. Jason S. DEROUCHIE, Jason GILE and Kenneth J. TURNER, Winona Lake: Eisenbrauns, 2013 , pp. 450-451.

32 M. Daniel CARROLL R., Welcoming the Stranger, pp. 447-448 cites the texts Num 27:1-11; 36:1-12 (both texts concern the inheritance of Zelophehad's daughters) and further 1 Kings 21:1-3 as a practical example of perceiving land ownership in this way (Naboth's reaction to Ahab's request). 
all that he has to someone else, to whom he must be constantly accountable for his deeds and for the use of the property entrusted to him.

Equality requires equal opportunities and equal rights, but also equal obligations, including religious and cultic ones. It is therefore difficult to establish whether the legal texts enable or require absolute assimilation. To the Israelis they emphasise that they are to make the immigrant's assimilation possible, but at the same time indicate that assimilation is required of the immigrant. In the appeal to the Israelites this requirement is emphasised by their own negative experience from Egypt and also by a broader appeal to sympathy with the society's weaker members.

On the other hand, two passages are found in the legal texts which limit this fundamental openness in a radical way. Deut 23:4-8 speaks of admitting foreigners in 'the Lord's assembly' (יָהל יהוה and expressly states that Moabites and Ammonites may never be admitted, not even in the tenth generation. The precise meaning of the term 'the Lord's assembly' is not clear here. It can be an expression of the full integration of an individual in the host community, ${ }^{33}$ a cultic assembly of free men, ${ }^{34}$ or something similar. On the one hand, this text does not identify 'the Lord's assembly' with 'the assembly of Israel', i.e., it does not speak of full membership in the nation, nor does it say that all Israelites automatically belong in the Lord's assembly. But at the same time the text goes much further than the requirement of excluding from integration. It urges the Israelites never to strive for their peace or good, which in covenant terms rejects any social or political relationship'. ${ }^{35}$ But the Edomites ('brothers') and Egyptians ('former hosts') can be admitted in the third generation. Waiting for full integration in the host community until the third generation ${ }^{36}$ is itself a great hindrance, especially when one recalls that in the context it is to be an expression of an openness towards Edom and Egypt. But this text (Deut 23:2-9) is not primarily concerned with the relationship to foreigners, but with admitting into 'the Lord's assembly' (influenced not only by nationality, but also by bodily state or origin). Although the issue of integrating foreigners is important in these verses, it is at the same time merely partial and limited to some nations. This text also assumes that foreigners (Moabites, Ammonites, Egyptians and Edomites) are living in the land of Israel and only the issue of integrating them into 'the Lord's assembly' is discussed. One can also say that the Lord's assembly is principally open to all foreigners with the exclusion of two nations and a limitation in the case of two others. ${ }^{37}$

The other text is concerned with intermarriage between the Israelites and other nations. In the land where remnants of the original population are present among the Israelites, mixed marriages must not be contracted. Deut 7:1-4 lists the relevant nations (the Hittites, the Girgashites,

33 Cf. M. Daniel CARROLL R., Welcoming the Stranger, pp. 454-455.

34 Cf. Irene SCHULMEISTER, Signale von „Grenzkonstruktion“ und „Grenzdestruktion“ in Dtn 23,2-9 und Jes 56,1-8, in: Zugänge zum Fremden. Methodisch-hermeneutische Perspektiven zu einem biblischen Thema, ed. Gerlinde BAUMANN et al., Peter Lang, 2012, p. 33, with reference to Georg BRAULIK, Deuteronomium 16,18-34,12, Würzburg, 1992, p. 170. Frank Lothar HOSSFELD and Eva Martina KINDL, קהל, in: Theologisches Wörterbuch zum Alten Testament, vol. 6, ed. Heinz-Josef FABRY and Helmer RINGGREN, Stuttgart, Berlin, Köln, Mainz: W. Kohlhammer, 1989, col. 1211-1212 speaks of a 'cultic-sexual' or 'religious-cultic' definition based on closest context. Christiana VAN HOUTEN, The Alien in Israelite Law, Sheffield: Sheffield Academic Press, 1991, pp. 99-101 speaks of 'full-fledged citizens who can participate in the cult and in military service'.

35 Irene SCHULMEISTER, Signale, pp. 38-39.

36 Carroll believes that the numbers ten and three signifying the relevant number of generations are symbolic. In the case of the number 'ten' it is obvious, as the text supplements it with the expression 'never'. On the other hand, the number three indicates a much more positive attitude and the difference is apparently intended to be emphasised. So it need not be the 'third generation' in the true sense of the word. But the text stipulates some delay before acceptance into 'the Lord's assembly'; it certainly does not speak of the immediate incorporation of an immigrant from Edom or Egypt. Cf. M. Daniel CARROLL R., Welcoming the Stranger, p. 453.

37 Cf. Irene SCHULMEISTER, Signale, pp. 40-41. 
the Amorites, the Canaanites, the Perizzites, the Hivites, and the Jebusites) ${ }^{38}$ and says: 'You shall make no covenant with them and show no mercy to them. You shall not intermarry with them, giving your daughters to their sons or taking their daughters for your sons.' This text also goes further than just preventing closer contact between the communities, because it emphasises that the Israelites are to destroy and eradicate those nations, 'for they would turn your sons away from following me, to serve other Gods. Then the anger of the Lord would be kindled against you, and he would destroy you quickly.' Although this text does not express a rule for the life of the following generation, but primarily for the one generation entering the Promised Land, it will nonetheless be applied at the time of the new arrival to the land after the Babylonian captivity (see further).

\subsection{Narrative texts}

The most typical narrative text dealing with the issue of foreigners among the Israelites in a novelistic form is the Book of Ruth. The main character is first the wife of an immigrant. When her husband, brother-in-law and father-in-law die, her widowed mother-in-law Naomi is preparing to return home and urging her Moabite daughters-in-law to return to the house of their mother. While Orpah decides to obey Naomi, Ruth stays with her mother-in-law.

Many of the individual characters' motives are concealed. ${ }^{39}$ We don't know why Ruth decided to follow Naomi: was it because she loved her mother-in-law, or because unlike Orpah she had nowhere else to go? Or in other words, was it an act of mercy and loyalty to Naomi, or an act of desperation? Was Naomi happy about it, or did it annoy her? Her reaction to Ruth's confession (Ruth 1:16-17) is not recorded. Upon arriving in Judea, Naomi does not introduce Ruth to anyone. Is she ignoring her, or is the author's silence accidental? Ruth expresses her attitude in 1:16-17, when she tells Naomi: 'Where you go I will go, and where you lodge I will lodge. Your people shall be my people, and your God my God. Where you die I will die, and there I will be buried. May the Lord do so to me and more also if anything but death parts me from you,' Similarly, Boaz later comments on her deed with these words: "All that you have done for your mother-in-law since the death of your husband has been fully told to me, and how you left your father and mother and your native land and came to a people that you did not know before. The Lord repay you for what you have done, and a full reward be given you by the Lord, the God of Israel, under whose wings you have come to take refuge. (Ruth 2:11-12)" So whatever the motivation of the main characters' acts is, it is presented and perceived by the surroundings as an act of mercy and loyalty.

Ruth's act is evaluated as an absolute break with the past and adhering to a new people in a new land. Her words are 'a clear confession of a legal status, of abandoning one legal bond with her own people and faith together with the right to be buried in the family grave and entering an entirely new situation, namely the situation of the widow Naomi from Bethlehem. That concerns ... life, habitation, membership in a people, faith, and grave. ${ }^{30}$ Ruth's whole confession is charac-

38 It is a classical and schematised list of nations in a more or less fixed form; see the conventional label 'seven nations' in Deut 7:1. They represent a summary specification of all the original nations of Canaan.

39 Cf. M. Daniel CARROLL R., Once a Stranger, Always a Stranger? Immigration, Assimilation, and the Book of Ruth, International Bulletin of Mission Research 4/2015, p. 186. Donatella SCAIOLA, Rut. Nuova versione, introduzione e commento, Milano: Paoline, 2009, p. 87 perceives Naomi's reaction to Ruth's confession as 'frosty'.

40 Hans Wilhelm HERZBERG, Die Bücher Josua, Richter, Ruth, Göttingen: Vandenhoeck \& Ruprecht, 1985, p. 264. 
terised by loyalty to Naomi - her nation will be Ruth's nation, her God will be the Moabite's God, etc. ${ }^{41}$ - and it is a clear signal of a fundamental discontinuity in her life. She renounces one 'rest'

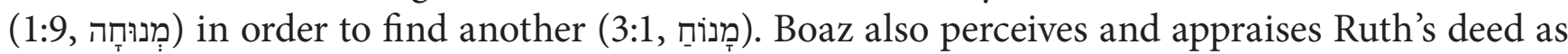
an act of mercy, and precisely for that reason wishes that the Lord repay her.

Ruth's act is commonly likened to Abram's departure from his homeland in Mesopotamia. ${ }^{42}$ Both leave their home and all they had known for ever and set out into the unknown, entrusting themselves in the Lord's hands. Although Ruth's deed may have been an act of desperation, it is evaluated and perceived from a positive aspect.

The acceptance on the part of the Bethlehem community is not as fast and radical as Ruth's decision. In direct speech Ruth is always designated as 'Ruth the Moabite' (4:5.10), and the narrator also speaks of her in this way three times $(1: 22 ; 2: 2.21)$. She is potentially exposed to harassment (as Boaz admits in 2:9): she and Naomi, being widows, are without an income and depend upon what is given to them or left in the field. At the same time some of the members of the new community are apparently welcoming, especially Boaz, who indirectly takes her under his protection and allows her to glean in his field, even telling his workers to intentionally leave something lying on the ground for her, even though he thereby risks acquiring a bad reputation because of a relationship with a foreigner, and a Moabite at that. Perhaps that is why he sends Ruth away from his threshing floor secretly. 'Ruth the Moabite' is the reason why Naomi's closest redeemer renounces his right/obligation (4:5-6). Despite that, Ruth eventually becomes a full-fledged member of Bethlehem society and even obtains a place in the royal lineage (4:18-22).

Ruth is not the only example. The Old Testament knows other foreigners who were fully integrated into Israelite society, for example Rahab (Josh 6:25), Achior (Jdt 14:10), and others.

Sometimes the opinion is encountered that the Book of Ruth was written, among others, as a reaction to the radical cleansing regulations enforced by Ezra and Nehemiah. ${ }^{43}$ It is true that in their respective conclusions these two books speak of the problem of the Jewish population's assimilation with the surrounding nations. It is not a situation when the Israelites are a host society, but a situation when they are a migrant society. But insofar as they regard themselves as a society settled in its homeland, which must face intensive confrontation with the surrounding nations, it is the first type.

The two books speak of the community becoming conscious of its own guilt, which consists in an insufficient separation from the surrounding nations (Ezra 9; Neh 9). The main topic of these chapters is the identity of the Jewish nation expressed by a disidentification with the 'foreign' (cf.

41 As Scaiola notes, Ruth's words about 'your' and 'my' God are not a confession of religious affiliation, but of personal loyalty to Naomi; this also applies to Ruth's statement that she wants to share her grave. The significance of this stands out for example in comparison with Jacob's or Joseph's wish to be buried in Canaan (Gen 50:5,12-13; 50:25). Cf. Donatella SCAIOLA, Rut, pp. 86-87. Extrabiblical texts can also be referred to, such as the Story of Sinuhe (cf. František LEXA, Výbor ze starši literatury egyptské, Praha: Šolc a Šimáček, 1947, pp. 31-44, esp. pp. 37 and 44).

42 See Hans Wilhelm HERZBERG, Die Bücher Josua, Richter, Ruth, pp. 264-265; Irmtraud FISCHER, Rut, Freiburg, Basel and Wien: Herder, 2001, p. 177; for a brief summary of the arguments of similarity and dissimilarity between the two characters see Donatella SCAIOLA, Rut, p. 225, the details are found in the relevant places in the course of the commentary. Wilhelm RUDOLPH, Das Buch Ruth, das Hohe Lied, die Klagelieder, Berlin: Evangelische Verlagsanstalt, 1970, p. 43 rejects this comparison because Ruth, unlike Abram, changed her deity; I regard this as a minor detail, not disturbing the picture of a radical and absolute life change, which is of the same nature in both characters.

43 Cf. for example. Donatella SCAIOLA, Rut, pp. 252-253; and others. 
Neh 13:30a: 'Thus I cleansed them from everything foreign'; and elsewhere). In his prayer (Ezra 9) Ezra finds the main cause of the punishment God has sent upon the elected nation in that they 'have not separated themselves from the peoples of the lands with their abominations, from the Canaanites, the Hittites, the Perizzites, the Jebusites, the Ammonites, the Moabites, the Egyptians, and the Amorites. ${ }^{44}$ For they have taken some of their daughters to be wives for themselves and for their sons.' (Ezra 9:1-2) This is perceived as a violation of God's commandment prohibiting intermarriage. In both cases there follows the decision to make a covenant with God (Ezra 10:3) or assume an obligation (Neh 10:1) consisting in dismissing all foreign wives (Ezra 10:2-4) or in several points, of which such dismissal is one (Neh 10:31). In Neh 13, Nehemiah states the unsatisfactory situation among the Jews and decides to rectify it. The issue of intermarriage is raised again (Neh 13:23-28). Neh 13:24 discloses that the reason is the same as in the legal texts of the Old Testament, namely that by their upbringing the wives-mothers take the children away from the Jewish faith. But Nehemiah applies a cultural criterion, namely that their children cannot speak 'Jewish'. The cultural identity expressed by language coincides with religious identity, which is understandable in the case of ancient Israel. Neh 13:1-2 also mentions the exclusion of the Ammonites and Moabites from 'God's assembly' (see Deut 23:4-8), which seems to be interpreted here very broadly, both as to the meaning of the term 'God's assembly' (Israel), and 'Am-

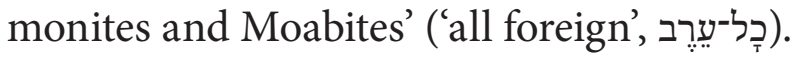

The abovementioned radical steps with xenophobic elements disclose the struggle for the endangered national-religious identity, which is firmly embedded in a covenant relationship with God.

\section{Summary and possible ethical significance}

The Old Testament views foreigners from two major perspectives: they are vulnerable, weak individuals in the society, who need help and protection; and at the same time, they pose a threat to the religious identity and purity of the Israeli nation. A similar dual view is also outlined in the migratory experience of Israel in the tension between the openness of a host society and clinging to keeping its own faith. Seeking harmony between these two aspects permeates the relevant Old Testament texts, whereby none of the texts mentioned above deal with an acute collision of these two perspectives.

The first perspective leads to an attitude which is manifested in the Old Testament passages that reflect on the migrants' life situation and reckon with a de facto absolute assimilation. The laws oblige both sides to it; the Israeli nation is expected to enable it and the migrants are expected to accept it, even with respect to the cult. The laws also emphasise that there must be no a priori discrimination of immigrants. The narrative texts also assume assimilation: Ruth is fully integrated into the tribe of Judah; as part of this tribe she even becomes King David's great-grandmother. On the opposite side, Daniel and his friends, Esther and Tobit become full citizens of the foreign society and faithful subjects of a heathen king.

44 In this text the list is significantly updated according to the present situation. While Deut 7:1-4 lists the Hittites, the Girgashites, the Amorites, the Canaanites, the Perizzites, the Hivites, and the Jebusites, Ezra adjusts the list by leaving out several names and inserting others, which were key nations in the given historical context (the Ammonites, the Moabites, and the Egyptians). Francesco BIANCHI, Esdra - Neemia. Introduzione, traduzione e commento, Cinisello Balsamo: San Paolo, 2011, p. 95 proposes to read Edomites, rather than Amorites, which would constitute another updating step. 
Perceiving immigrants as enemies and being afraid of them is quite natural. Sir 11:34 is fully aware of that: 'Give a home to a stranger and he will start trouble and estrange you from your own family.' If other Old Testament texts require a different attitude, they do so based upon extensive theological motivation. ${ }^{45}$ The experience of a migrant is in the foundations of the very existence of the Israeli nation and its theology. Although the significance of the Egyptian slavery and of the exodus from Egypt for the Old Testament in general and for the issue of migration and the attitude to migrants cannot be overestimated, the memory of the forefathers' wandering is also retained, which results in perceiving the national and personal life as the life of a perpetual foreigner. The positive attitudes to foreigners in the Old Testament are therefore motivated correspondingly. The reason is their own (national, not necessarily personal) historical experience, gratitude to God and awareness of the demand placed on the human being by the relationship with his God-redeemer.

The other mentioned perspective, i.e., the awareness that the foreigner poses a threat to the religious integrity of the Israeli host society is also theologically motivated. That is why the only exception from the full assimilation mentioned above is a situation that would endanger Israel's relationship with its God and result in a breach of the First Commandment. This requirement also creates something that could be perceived as an imbalance. The Israeli nation requires immigrants to become religiously assimilated and where it may not occur, for example in situations of intermarriage, we encounter uncompromising laws. The foreigner is welcome and - insofar as he is a weak and vulnerable individual - is the object of appropriate care, but he must not endanger the religious identity of the Israeli nation. On the other hand, religious assimilation is the only thing that the heroes of Old Testament diaspora stories resist, even to the point of suffering or death. So, to speak, for example in the case of the Book of Daniel, of religious freedom is misleading, ${ }^{46}$ since Old Testament texts demand it in this sense only for Israel. If this attitude appears to be applying a double measure, it is necessary to add that the Old Testament assumes a contractual relationship of God with the nation. It does not force any foreigner to change his faith and adopt Judaism; it merely strives to ensure that the Israelites or Jews as a nation (because God made the covenant with the nation and the nation is evaluated and bears the consequences of its actions) can keep the covenant with God. ${ }^{47}$ It is the position of someone who is conscious of his values (expressed in contemporary terms) and is convinced of the significance of his relationship with God, to which no other confession is equal, and of its key role in survival (Israel's unfaithfulness to God results in the nation's destruction). Precisely the collective responsibility for the relationship of the nation with God necessarily leads to defending the collective against possible infiltration and disintegration by unassimilated foreigners. Assimilation is limited by reason of a single 'higher good', which is religious practice and faithfulness to the covenant with God. ${ }^{48}$

This study began with an ethical enquiry, to which it is now necessary to return. Considering the possible interface with the present situation in Europe, several items need to be pointed out.

The Old Testament perceives migration as a common human experience. For various reasons,

45 Cf. Gianni BARBIERO, Lo straniero nel Codice dell'Alleanza e nel Codice di Santità: tra separazione e accoglienza, Ricerche storico bibliche 1-2/1996, p. 69.

46 In this sense the claim in Adam MACKERLE, Danielovy dvorské př́běhy, p. 54 needs to be corrected; cf. also John J. COLLINS, Daniel: A Commentary on the Book of Daniel, Minneapolis: Fortress, 1993, p. 194.

47 See the typical example of the ruler's 'non-conversion' in the Book of Daniel (Adam MACKERLE, Danielovy dvorské příběhy, p. 48).

48 On the nature of religious faith in the Old Testament cf. Martin PRUDKÝ, Vztah k jiným náboženstvím ve Starém zákoně, in: Křestané a jiná náboženství, ed. Karel TASCHNER and Pavel HOŠEK, Praha: Návrat domů, 2004, pp. 15 and 19. 
individuals, families and nations are on the way. In that, the issue of the cohabitation of the host community and the immigrants needs to be addressed. The situation of the contemporary world does not differ much in this respect. In 2013 there were approximately 232 million international migrants in the world; ${ }^{49}$ in 2015 the number grew to 244 million (the number of refugees in 2014 is estimated at 19.5 million). ${ }^{50}$ Of course, the legal texts of the Old Testament speak only of the migration of individuals, not of nations or large groups, and the case is similar with the narrative texts. The migration policy will be different if it faces a smaller number of migrants consecutively arriving in the country, or a massive influx of nationally more or less homogeneous foreigners. All this must warn us not to apply the narrative (and especially legal) texts of the Old Testament to the contemporary situation in an over-simplistic way.

As for theological reasoning for taking care of foreigners based on the historical national or even personal experience of received grace, I have only exceptionally encountered such reasoning with respect to the migration of refugees to Europe. It is an essentially theological argument, an awareness that I myself am a foreigner in my land, that I do not possess the land, that it has been bestowed on me, and I should therefore be similarly generous to those who are in need and cannot or are afraid to live in their native land. If I have some life security, it always remains an undeserved grace freely given (gratia gratis data), which cannot be transformed into an inalienable ownership right. ${ }^{51}$

In the case of the other perspective, i.e., the fact that in the Old Testament foreigners are perceived as a threat to religious identity, the contradictory moment consists in what individual host communities feel threatened about nowadays. Immigrants may draw out the limited resources of the country, or they may pose a threat to the safety of the native inhabitants or their cultural identity. Neither is addressed by the Old Testament, and in the case of 'culture' (in the sense of language, dress code, sustenance, social behavioural patterns, etc.) it reckons with assimilation. The only absolutely defended good is faithfulness to the covenant with God. The 'cultural' sphere comes into focus in the Book of Nehemiah, which perceives a command of the language as an essential part and manifestation of the religious identity (although it is also true that the nations whose assimilation is discussed by the Old Testament are culturally and linguistically very close to Israel). Here the Old Testament speaks of something we do not know, since the idea of collective religious responsibility before God, so typical of the Old Testament, is unknown in contemporary Europe. There is no wonder that the topic of a threat to the religious relationship of the European nation with God due to an influx of persons of a different faith is absent from the contemporary reflections on migration; usually the issue of a threat to 'civilisation', 'culture' or 'values' is discussed,

49 Cf. (C) UNITED NATIONS, DEPARTMENT OF ECONOMICS AND SOCIAL AFFAIRS - ORGANISATION FOR ECONOMIC CO-OPERATION AND DEVELOPMENT, World Migration in Figures. A joint contribution by UN-DESA and the OECD to the United Nations High-Level Dialogue on Migration and Development, 3-4 October 2013, p. 1 (online), at: https://www.google.cz/url? sa=t\&rct=j\&q=\&esrc=s\&source=web\&cd=1\&cad=rja\&uact=8\&ved=0ahUKEwij2Oin2LHLAhUljXIKHfW1Dp4QFggcMAA\&url=http\%3A\%2F\%2Fwww.oecd.org\%2Fels\%2Fmig\%2FWorld-Migration-in-Figures.pdf\&usg=AFQjCNHoHr6iigJdpFy4UPr-finNZnszZQ\&sig2=VwfQJRU8JcA9gsyaKJySsA, accessed 7 March 2016.

50 Cf. () UNITED NATIONS, DEPARTMENT OF ECONOMICS AND SOCIAL AFFAIRS, International Migration Report 2015, New York: United Nations, 2016, p. 1 (online), at: https://www.google.cz/url?sa=t\&rct=j\&q=\&esrc=s\&source=web\&cd=3\&cad=rja\&uact=8\&ved=0ahUKEwik68S02rHLAhXnwHIKHfTiB64QFgglMAI\&url=http\%3A\%2F\%2Fwww.un.org\%2Fen\%2Fdevelopment\%2Fdesa\%2Fpopulation\%2Fmigration\%2Fpublications\%2Fmigrationreport\%2Fdocs\%2FMigrationReport2015_Highlights. pdf\&usg=AFQjCNFrffaHkSjAOl0KPutbAkmiilbgPQ\&sig2=qxi70AfZME6mySzAla52jg, accessed 7 March 2016. The subsequent specification of what percentage of migrants and refugees there are in which countries shows that there is an unequal distribution and thereby also the fact that the 'problem' of migrants does not concern all countries in the same way and that the differences are significant.

51 Cf. Josef Bohumil SOUČEK, Příchozí a poutníci, p. 113. 
which is of course something quite different. ${ }^{52}$ So the Old Testament is significantly silent on the question of the correct Christian attitude to migrants who potentially endanger the national or cultural identity, unless texts are taken into account that require one side to make assimilation into the majority society possible and at the same time require the other side to acknowledge that assimilation as justified. It is not a problem the Old Testament would address. So the question is whether the professed values ought not to be re-evaluated in this light.

If we endorse the view of Birch and Rasmussen, we will expect the Bible merely to contribute to the debate over the issue of migration, not to solve it. In this sense, it turns out that if one wants to 'apply' the Old Testament's view to the issue of migration that has been taking place in Europe in the recent years, as well as migration into Europe in the course of the last decade, it means in the first place that one needs to radically change the point of view on the issue and consider theological arguments. If there are some constant elements in the plurality of Old Testament texts and genres concerning migration, it is precisely a theologically grounded reasoning, which may sometimes uncomfortably go against what emotions, fears, or even some purely rational arguments dictate to us. Precisely in this sense do Old Testament texts pose a challenge to the contemporary reader.

52 The difference between 'culture' and 'religious identity' must be retained; in this sense the wording of ๑) Výzva predsednictva ČBK $k$ rozeznění zvonů, 29. 7. 2016 (online), at: http://www.cirkev.cz/cs/aktuality/160729vyzva-predsednictva-cbk-k-rozezneni-zvonu, accessed 21 September 2016, is quite infelicitous, as it seems to confuse these concepts. 


\title{
'We Are Strangers Before You and Sojourners, As All Our Fathers Were' (1 Chr 29:15). The Old Testament's Contribution to the Ethical Issue of Migration
}

\begin{abstract}
The paper discusses the Old Testament's witness on the issue of migration. It provides an overview of the most basic relevant texts and divides them into two groups: the witness of Israel as a migrant and the witness of Israel as a host. Without claiming completeness, the paper attempts to summarise in what sense texts can contribute to contemporary ethical discourse on the topic of migration. From the social-economic point of view the refugees are a category of people who are to be helped, but who at the same time pose a threat to the religious integrity of Israel. In a social-cultural and religious sense the Old Testament therefore requires and at the same time assumes the assimilation of the migrants, albeit with the principal exception that neither a migrant nor a host may endanger Israel's right to its relationship with God. However, all texts agree that theological reasoning referring to Israel's own past as a migrant and to a lesser extent to the present state of the migrant before God is always decisive/determining. Precisely this rigorous theological reasoning of both attitudes (welcoming and reserved) is the main constant element and at the same time a challenge to the contemporary reader.
\end{abstract}

Keywords: migration, Old Testament, foreigner, Bible ethics

\section{Author contact}

\section{Dr. Adam Mackerle}

University of South Bohemia, České Budějovice

Faculty of Theology, Department of Theological Disciplines

Kněžská 8, 37001 České Budějovice

mackerle@tf.jcu.cz 